\title{
7 \\ Beyond Consumasia: The neglected challenges
}

Tessa Morris-Suzuki

\section{Which Asia?}

The issue of engaging with Asia raises a question posed by Mahatma Gandhi almost 70 years ago: 'Which Asia?' In March 1947, the first major postwar Asian gathering, the Asian Relations Conference, was held in New Delhi to 'foster mutual contact and understanding' among the nations of the region. One of the speakers was Gandhi, who addressed the closing session. When first invited to this meeting of representatives from all over Asia, though, Gandhi's characteristic response had been to pose a question: which Asia, he asked, would be present at the conference (cited in Samaddar 1996: 40). Reading the White Paper on Australia in the Asian Century, I found myself recalling Gandhi's question. The White Paper's executive summary begins with a series of ringing declarations:

Asia's rise is changing the world. This is the defining feature of the 21st century - the Asian century ... Asia's extraordinary ascent has already changed the Australian economy, society and strategic environment ... Australia is located in the right place at the right time - in the Asian region in the Asian century. (Commonwealth of Australia 2012: Executive Summary 1) 
Yes, but ... which Asia?

The answer is not difficult to discern. The White Paper's executive summary goes on to tell us that

within only a few years, Asia will not only be the world's largest producer of goods and services, it will also be the world's largest consumer of them. It is already the most populous region in the world. In the future, it will also be home to the majority of the world's middle class. (Commonwealth of Australia 2012: Executive Summary 1)

These words - growth, consumers, middle class - run like a mantra throughout the White Paper. Little boxes in the text give us glimpses of the Asians with whom Australia (but which Australia?) will interact: the stockbroker in Ahmedabad who owns a washing machine, a refrigerator, a television, a DVD player and two mobile phones, 'all of which, with the exception of the refrigerator, are international brands' (Commonwealth of Australia 2012: 64); the Chinese, Indian and Thai tourists who enjoy 'personal experiences customized for customers from Asian countries' at Tangalooma Island Resort (Commonwealth of Australia 2012: 97); the 33,000 accountants across the Asian region who are certified practising accountants with CPA Australia; the highly educated Asian migrants whose technical expertise is boosting Australian economic growth.

In as far as it goes, this is, of course, all true. Many (though not all) countries of Asia are experiencing remarkable rates of economic growth. In many, the size of the middle class is expanding rapidly. Australia's economic fortunes are profoundly dependent on those of the region, and efforts to improve Australian education about and understanding of Asia are to be applauded. The problem is that, in the end, the reader of the White Paper is left with an image of 'Asians' that is utterly different from, but in some ways as one-dimensional as, the images that abounded in Australian, European and US writings about Asia at the height of the Cold War. Then, Asians were poor, hungry, downtrodden and susceptible to the dangerous allure of communism. Now they are upwardly mobile and possessed of marketable skills and an apparently insatiable appetite for the globalised allure of consumerism. Cold War Orientalism presented us with Asians entangled in the ancient bonds of patriarchal families and traditional communities. The White Paper offers us 'Consumasians' - their identities defined by their shopping list of brand-name goods and their folio of graduation certificates.

While the White Paper was being debated in the Australian media, the media was also reporting concerns over the health of 170 asylum-seekers who were on hunger strike in the detention centre on Nauru, having been sent there by an Australia which refuses to abide by its Geneva Convention obligations to process the refugee claims of boat people on its territory. As of January 2015, 
there were more than 1,800 asylum-seekers detained in overcrowded conditions on Nauru and Manus Island detention centres, many of them from Iran, Afghanistan, Sri Lanka, Myanmar, Bangladesh and other Asian countries, and these detainees were just the tip of a very large iceberg (Australian Customs and Border Protection Service 2015; Hall 2012).

The refugees detained on Nauru and Manus Island should not be seen as representing a separate, poor and suffering Asia to be considered alongside the White Paper's Consumasia. Rather, they are the same people. Many of the detainees, too, are highly educated and in search of upward mobility; almost all of them want a better material life for themselves and their families. They too want to participate in the material abundance of consumer society. To recognise this is not to deny that many have also genuinely suffered fear, violence and persecution in their home countries. The people detained indefinitely in inhumane conditions on Nauru and Manus Island are not the 'other' of the globalised, economically expanding Asia depicted in the White Paper; they are an integral part of that Asia, another dimension of the same complex region, a dimension that complicates the picture.

Which face of 'Asia' do we recognise? With which dimension of Asia will we interact, and how?

\section{The other Cold War}

The White Paper, to be fair, does acknowledge some of the complexities. It notes that rapid growth in Asian economic powerhouses such as China and India comes with costs, which include widening gaps between rich and poor and deepening environmental challenges. However, by placing the rise of Asia so squarely in an economic framework - by viewing it almost exclusively through the prism of free-market globalisation - the White Paper obscures some important dimensions of regional change and regional interaction, which become clearly evident if we use other prisms for considering events in the region.

For social scientists and other researchers engaging with various parts of Asia, it is (I would suggest) important to consider the region though a different prism: that of the end of the Cold War and the creation of a post-Cold War order. It is interesting that the White Paper makes only the most fleeting references to the Cold War as an event of a vague and seemingly rather distant past. Reading it with no prior knowledge, you would not guess that there had ever been such things as communism or Maoism. The Vietnam War gets just one mention in the context of migration to Australia, and there is also a single reference to the 'Korean War wool boom'. Yet it could be (and often has been) argued that the 
economic rise of Japan, South Korea, Taiwan and other economies was closely related to the structures and events of the Cold War. It could also be argued that what is happening in Asia today is all about the uncertain end of the Cold War. Looking at events through this prism, though, requires us to rethink some aspects of conventional wisdom about the Cold War as well as about the rise of Asia'.

As Cambridge-based Korean scholar Kwon Heonik observes in his book The other Cold War:

In the media and across academic communities, it is widely assumed that the cold war era ended when the Berlin Wall fell in November 1989. In the subsequent decade, 'after the fall' became the most popular means to express what was then perceived to be the new, hopeful spirit of the time and to contextualize contemporaneous events and developments on the basis of a radical rupture in time ... The general consensus about the end of the cold war in chronological terms relates to a broad consensus about the moral implications of the great End. The Cold War ended because the Communist system ran out of steam to compete with the capitalist economy and liberal democracy. (Kwon 2010: 4-5)

As Kwon also points out, however, things look very different if you view the Cold War from the perspective of East Asia, particularly (perhaps) from the perspective of Korea. There, of course, despite all the massive transformations of the past three decades, the Cold War has never really finished. The peninsula remains divided by a line even more impenetrable and fiercely guarded than the erstwhile Berlin Wall. Sixty years after the Panmunjom Armistice, no peace treaty has ever been signed to conclude the Korean War. Indeed, North and South Korea do not even have an armistice, since the South Korean government of the day refused to sign the Panmunjom agreement. More broadly, traces of Cold War thought and structure remain embedded in many parts of the region, whether in the US bases that still occupy much of the territory of Okinawa; in the Cold War military alliances that still, virtually unchanged, link Japan and South Korea to the United States; or in the spectres of Mao Zedong and Ho ChiMinh, whose presences, albeit often in disconcertingly twenty-first-century commodified forms, still haunt the physical and mental alleyways of significant parts of the region.

Looking at things from this perspective, we might tell a different story of the history of the Cold War. In this alternate narrative, the Cold War did not end abruptly in and around Berlin in 1989. Instead, the events that took place in Europe from the late 1980s to early 1990s were just the beginning of a long, slow ending - a gradual and uncertain transition to a post-Cold War order. The end of that ending is being played out here in our region - in East Asia and the Pacific - as we speak. This alternative geography and chronology produce a different, less comforting and more challenging set of moral implications. 
For example, they cast into question the moral narrative of the triumph of liberal democracy. The rise of China, and also of other smaller Asian economic powerhouses like Vietnam, shows no clear sign of being accompanied by the triumph of traditional Euro-American forms of liberal democracy, although it is being accompanied by a proliferation of complex and fascinating forms of local activism, and by a churning up of established political ideas. Engaging seriously with this churning of ideas is likely to require something much more profound than 'Asia literacy'. It may require a willingness to rethink some of our most deeply seated assumptions about the nature of political debate and even about the meaning of politics itself.

Viewing Asia (and particularly East Asia) through the prism of a transition to a post-Cold War order, rather than through the prism of globalised market liberalism, does not necessarily produce a pessimistic view of our region's future, but it does produce a more conjectural view. It casts a sharp spotlight on the uncertainties. How will rising powers such as India and China relate to one another, to the old Cold War great powers Russia and the United States, and to less rapidly growing neighbours such as Japan? Are the economic forces drawing the region together strong enough to resist the political forces that sometimes threaten to pull it apart? The answers to these questions cannot be extrapolated from the present in the way that the White Paper extrapolates future demographic and even economic growth rates, for they depend on political and human contingencies. The region stands finely balanced on the cusp of history, and whether it tips in the direction of a new age of integration or (as some East Asian commentators have suggested) into a second Cold War depends on the choices that regional governments, including the Government of Australia, are making today.

A focus on the difficult and uncertain search for a post-Cold War order reminds us of the great social and conceptual challenges that confront the region. Consider, for example, one analogy. Since the fall of the Berlin Wall in 1989, some 4.3 million people from the former East Germany have left their homes to resettle in the western half of the reunited Germany or in other parts of Western Europe. Although 2.7 million westerners have moved into the east, the area that was once East Germany has lost about 10 per cent of its population. This mass migration has had huge social effects, not only on the receiving regions, but also on the towns and villages that the migrants left behind. The social effects are not experienced uniformly, not least because the migrants are drawn disproportionately from certain sections of the population. They are, by and large, younger and more educated than those who remain behind, and more than two-thirds of them are women. On top of problems of readjustment and sometimes of discrimination in the migrants' new home communities, the outflow of people has left serious age and gender imbalances in the communities 
they have left behind. One major study of the phenomenon suggests that the concomitant feelings of insecurity have contributed significantly to the rise of neo-Nazism in the former East Germany (Berlin Institut für Bevölkerung und Entwicklung 2007).

The social challenges of a transformation on the divided Korean Peninsula are vastly greater than those that were faced by Germany. East German gross domestic product (GDP) per capita on the eve of German reunification has been estimated to be about 59 per cent of West German GDP per capita. As of 2011, North Korean per capita GDP is estimated to be less than 6 per cent of the South Korean level (Bennett 2013: 26; de Groot et al. 2004: 71). Now imagine what will happen when North Korea, even if it is not reunited with South Korea, starts seriously to open its doors to the rest of the region, as it is almost certain to do with the gradual melting of the last fragments of the region's Cold War ice.

\section{East Asia's impending refugee crisis}

I highlight the Korean crisis, both because it is one of the most significant crises facing our region in the Asian century and because it provides one vivid illustration of a crucial regional dilemma that the White Paper does little to address. Of course, there is no particular reason to think that the division between the two Koreas will collapse dramatically, as did the division between the two Germanies. If it did, though, such a collapse would have drastic and indeed almost catastrophic implications for South Korea. Ultimately, in whatever way, greater integration of North Korea into the region will take place, and the effects of this on neighbouring countries - particularly, but not exclusively, South Korea - will be enormous.

The situation in North Korea (the Democratic People's Republic of Korea, DPRK) today is widely misunderstood and misreported in the international press, and is barely mentioned in the White Paper. A particularly widespread misconception is that North Korea is somehow frozen in an unchanging state of communist dictatorship. This view arises from the fact that, at the level of the national leadership, very little has changed in recent years. The reins of power have passed from the founding father, Kim Il-sung (1912-94), to his son Kim Jongil (1941-2011), and then to his grandson Kim Jong-un. Following the massive famine of the mid-1990s, in which about one million North Koreans are believed to have died, there were some signs of efforts to relax controls on the economy in the late 1990s and the first years of the twenty-first century. Thereafter, though, the government has returned to a repressive policy of attempting to maintain tight controls on any market activity, and in 2009 the state enacted a disastrous re-denomination of the currency, which in effect amounted to a confiscation 
of the savings of ordinary North Koreans. Initial hints of impending economic liberalisation under the new leader, Kim Jong-un, have yet to produce noticeable effects.

If you look not at the state leadership but at what is happening at a grassroots level, though, a very different, but no less disturbing, picture emerges. Despite repeatedly enacted restrictions and prohibitions on market activity, the market is in fact flourishing and is, in a fascinating way, rising up from below to permeate and devour the structure of the official system. Ironically, then, North Korea provides a vivid example of the flourishing of Asian market economies, which the White Paper commends. The reason for this development in North Korea, however, is very simple: the official system does not work any more. Officially, North Korea has a planned economy in which all significant businesses and all land and real estate are owned by the state. All adult men, having finished a period of universal conscription that lasts for up to six years, are provided with jobs by the state, and the state distribution system (in theory) provides rations of basic foodstuffs to all families on the basis of their consumption needs. In practice, this system has been in a state of collapse for at least the past 15 years. The state distribution system barely functions, and jobs allocated in state-owned enterprises quite often involve very little work and no pay.

One consequence of this collapse is economic catastrophe. North Korea is the only part of our region that stands on the brink of large-scale famine. According to a 2012 UN nutritional survey, some 28 per cent of North Korean children under the age of five show signs of chronic malnutrition that will stunt their future growth and development (Agence France-Presse 2013). A key factor behind the nutritional crisis is a chronic energy shortage. Since the fall of the Soviet Union and other communist regimes, which were major economic supporters and trade partners of the DPRK, North Korea has lacked the energy needed for industry and domestic use, and particularly to produce the fertilisers that are needed to sustain the scientifically selected breeds of rice and other crops introduced in its earlier attempts to boost food production. Fertiliser shortages result in poor yields and soil exhaustion. Meanwhile, fuel shortages lead to the cutting of forests, resulting in massive deforestation, soil erosion, landslides and flooding, further reducing crop yields. Malnutrition is linked to the spread of diseaseparticularly tuberculosis (TB). The World Health Organization (WHO) estimates the DPRK's rate of TB infection at 345 in 100,000 - one of the highest levels outside sub-Saharan Africa. Multi-drug-resistant TB is spreading particularly fast (Perry et al. 2011: 263).

The North Korean government, for all its many faults and failings, is neither ignorant of nor indifferent to these problems. Major reforestation programs are being attempted in various parts of the country. North Korean medical experts work with those from other countries and from organisations like WHO to try to 
tackle issues of malnutrition and disease. Gradual shifts in policy are leading to the modest expansion of a 'middle-class' consumer society centred on Pyongang. By early 2013, North Korea's mobile phone provider Koryolink had almost two million subscribers (Mirani 2013). As elsewhere, however, such developments also reflect growing gaps between rich and poor, city and country.

Meanwhile, the other side of the crisis is economic and social change, as people do what they have to do to survive. This means cultivating illegal plots of land on mountainsides, crossing the border illegally to buy goods in China in illegal street markets, making handicrafts to sell, and sometimes even setting up small enterprises illegally employing others. It is believed that during the famine of the 1990s, up to 300,000 North Koreans may have crossed into China in an attempt to find a means of survival, most of them subsequently returning to North Korea. At present, the number of North Koreans in China is well below the level of the late 1990s, but may well rise again if famine conditions persist. Within North Korea, meanwhile, the expanding illegal economy now extends surprisingly far. There are numerous reports of a flourishing real estate market in North Korea. North Koreans increasingly pay to exchange state-owned houses or apartments - some seeking to 'trade up' to more desirable residences while others supplement inadequate incomes by 'trading down'. Brokers act as intermediaries in this market. The spread of black or grey market activities is inevitably accompanied by growing corruption. According to one wellinformed source whom I interviewed, payments (preferably in foreign currency) are an important part of the process of acquiring membership of the ruling Korean Workers' Party, which is itself a necessary prerequisite for many of the country's most prestigious jobs.

Whatever happens at the leadership level, the massive problems that beset the country are not going away, and they have profound implications for North Korea's neighbours and for the Asia-Pacific region as a whole. Any attempt to reintegrate North Korea into the region will require an effort to address the vast problems - including poverty, malnutrition and energy shortages - that beset the country's people. Indeed, the more North Korea is reintegrated and opens its doors to the region, the more these problems will also affect surrounding countries. Left unaddressed, the massive wealth gap between North Korea and the rest of Northeast Asia will become an ongoing source of future social and economic insecurity. 


\section{Human flows and human security}

One result of extreme wealth gaps between neighbouring countries is the flow of people from poorer to richer countries. In Australia, recent very unproductive debates about refugee problems have focused on refugees from the Middle East, Afghanistan and Sri Lanka, but any opening of North Korea's doors, however this occurs, is going to lead to new mass movements of people (both within and across the borders of North Korea), which will affect the region, as well as affecting the society of the DPRK itself. Even now, when the Cold War dividing line remains as heavily guarded as ever, cross-border flows are substantial.

The largest group of North Korean emigrants and refugees is almost certainly in China, but the total number of North Koreans currently living in China is unknown. Some South Korean non-governmental organisations (NGOs) cite figures as high as 300,000. However, many scholars put the post-famine number at about 30,000-50,000 (Kim 2012: 45). China responds to the problem in essence by having no policy. It does not recognise undocumented migrants from North Korea as refugees, and officially has a policy of returning those apprehended to the DPRK (where they face imprisonment in terrible conditions). There is, however, abundant evidence to suggest that Chinese authorities do not pursue North Korean undocumented migrants vigorously unless expediency encourages them to do so. Meanwhile, as many as 40,000 North Koreans, including garment workers, mechanics and construction workers, have been encouraged to enter China legally under guest labour schemes (Demick 2012).

China has rightly been criticised by the outside world for its policy, which results in North Korean migrants living in fear, often in hiding, and vulnerable to extreme economic and often also sexual exploitation. It must be said that China is right in pointing out that a large number of North Koreans who cross the border do so primarily for economic rather than for political reasons, and are therefore not strictly speaking 'refugees' in the narrow definition of the Geneva Convention on the Status of Refugees. On the other hand, the Geneva Convention also prohibits 'refoulement' - that is, the practice of sending people (whether recognised as refugees or not) back to home countries where they are liable to persecution. China's practice of returning undocumented entrants to North Korea clearly flies in the face of this provision.

While human rights groups have been vocal in the criticism of China's treatment of North Korean emigrants, there have been few serious efforts by other countries of the region to engage China in dialogue on constructive responses to the problem - particularly on the possibility of creating strategies of 'orderly departure', which would enable North Korean refugees in China to leave for other countries where they could be resettled. An orderly departure program, if nothing else, might at least reduce the number of refugees relying on people 
smugglers to take them on long, arduous and extremely dangerous onward journeys from China to countries such as Laos, Mongolia or Burma, from where most seek to enter South Korea.

As of August 2012, South Korea had accepted more than 24,000 emigrants from the north, more than half of them arriving since the beginning of 2005 (Republic of Korea Ministry of Unification n.d.). South Korea treats all Koreans as its citizens. There is, therefore, no need for North Koreans who seek refuge in the south to go through a refugee recognition process. Major problems of adjustment, however, face many North Korean 'newly settled people' (saeteomin), as they are sometimes called in the south. The South Korean system continues to be based on a structure set in place at the height of the Cold War, when the small numbers of defectors from the north were almost all relatively high-ranking officials, military officers and so on, who were defecting for overtly ideological reasons. The system therefore begins by placing refugees, generally for about a month, in a closed facility for debriefing and identification checks. They are then transferred to a closed residential educational centre, the Hanawon, where they receive education in civics and life skills, designed to turn them into good South Korean citizens (O 2011). Some critics argue that a new approach is needed to assist today's generation of North Korean emigrants to adjust to life in the south. After they leave the Hanawon, refugees can continue to receive support at 30 local Hana centres, and also receive reasonably generous financial assistance from the state. Yet there is abundant evidence that North Korean refugees struggle with problems of social and cultural adaptation. Many suffer from post-traumatic stress disorder (PTSD), which often goes untreated. Unemployment is widespread, and their average wages are far below the South Korean norm. In January 2011, only about 50 per cent of North Korean refugees in the south were in paid employment, and most of those had manual labouring jobs. A study by Emma Campbell at The Australian National University notes that surveys show widespread negative views of North Korean refugees among South Koreans, including those of the younger generation. A 2008 national survey showed that more than half of young South Koreans were opposed to marrying someone from the north, and interview research has also shown that many South Koreans see migrants from the north as likely to be law-breakers or troublemakers (Campbell 2011).

A rapidly growing number of North Korean contract workers - probably now about 20,000 - are working on projects in the Russian Far East. There are also believed to be more than 1,000 North Korean refugees in Thailand, several hundred in Laos and Cambodia, an unknown number in Mongolia and about 200 in Japan. Further afield, the United Kingdom has accepted 280 North Korean refugees, Germany more than 200 and the United States 86. Australia does not accept North Korean asylum-seekers because, like many other countries, it accepts South Korea's official definition of all Koreans as being South Korean 
citizens, and therefore argues that North Korean refugees have a natural place of refuge in the south. As we shall see, however, this view raises serious problems and is likely to become increasingly untenable over time.

An important point to emphasise about the refugee flow from North Korea is that, even more than the movement of people that followed the fall of the Berlin Wall, it appears to be a gendered movement: of 20,407 North Korean refugees in South Korea in 2010, 14,030 - or almost 70 per cent-were women (ICG 2011). No reliable figures for North Koreans in China are available, but anecdotal evidence suggests that there, too, women substantially outnumber men.

\section{The role of Australia}

Is there a role for Australia in addressing this pressing human security crisis? I believe Australia could potentially play an extremely valuable and positive role, but is currently failing to do so. Although Australia is one of the countries that has a diplomatic relationship with North Korea, this relationship is entirely inactive, and has been for a number of years. In essence, we have put North Korea in the too-hard basket. Australia has continued to contribute to the World Food Program's projects in the DPRK, but otherwise has no aid or development relationship with North Korea and, since 2006, as part of sanctions related to North Korean nuclear testing, has refused to issue visas to North Koreans wishing to come to this country.

In this, we are out of step with many European countries, which have recognised the need for a more positive response to the humanitarian and human security crisis in North Korea. The European Union, for example, cooperates with a number of European governments in providing technical transfer and training programs to assist North Korea to overcome its massive problems of energy and food shortages, soil degradation and deforestation. Although direct food aid of the sort provided by the World Food Program is obviously important in times of crisis, agricultural development projects are likely to be of greater long-term benefit to North Korea's long-suffering people. Development and technical transfer projects are also less susceptible to aid diversion than donations of food.

A few examples can serve to indicate the possibilities. The Dutch government has a program with EU support to provide training for North Korean agricultural technicians in Wageningen University, and also to introduce disease-resistant potato varieties to North Korean agriculture. The Polish government also works with agricultural specialists in North Korea to develop improved methods of crop storage. One particularly interesting example of development support is a Swiss government scheme, developed in cooperation with the North Korean government, to help restore degraded mountainside using new agroforestry 
practices. An important reason for deforestation in North Korea is that food shortage has driven farmers into remote mountain areas where they secretly create their own private plots to grow food, in the process cutting or burning the natural tree cover. A key feature of the Swiss-North Korean project is that it works with local communities whose members have created illegal private plots, allowing them to continue farming the land on condition that they adopt new recommended soil conservation practices ( $\mathrm{Xu}$ et al. 2012).

Even the United States, North Korea's most vocal critic, seems to be engaging more closely with North Korean society than does Australia. Although there are no US government schemes to compare with the European ones just mentioned, there are significant examples of non-governmental development assistance. One of the most significant is the long-running project by the American Association for the Advancement of Science, Syracuse University and the US Civilian Research and Development Foundation to work with universities in North Korea to share resources and give lectures about issues including reafforestation, soil quality, river reclamation and agriculture (Taylor and Manyin 2011).

Because of its close economic integration with Northeast Asia, Australia is far more directly affected by events in North Korea than are countries like the Netherlands and Switzerland, and Australia also has a particularly rich store of expertise in areas such as agricultural research, soil regeneration and erosion control. Yet the Australian government and research establishment have completely failed to contribute to these initiatives. Given the current North Korean government's evident moves to attempt some cautious form of opening to the outside world, I would argue that now is the time for Australia to become actively involved in addressing North Korea's human security crisis through well-targeted training, technology transfer and agricultural development projects. The difficulties of running such projects cannot be denied. Careful planning would be needed to make sure that they are effective. Projects should start as small-scale pilots, and be expanded if they show promise. A move away from the too-hard-basket mentality towards cautious but active engagement would not only help to ease one of our region's most pressing humanitarian crises, but also help to make Australia better informed about North Korea and better prepared to respond to future transformations.

At the same time, Australia should not neglect the plight of North Korean refugees, who often struggle to cope even if they are given an opportunity to resettle in South Korea. Other countries, including the United Kingdom and Canada, have shown some degree of willingness to allow limited numbers of North Korean refugees to resettle in those countries, while the United Kingdom also assists North Korean refugees in South Korea by sponsoring English-language courses for them, run through the British Council. Since English-language skills are hard to obtain in North Korea, and are almost essential for career success in 
the south, this is a measure that is greatly appreciated by many former North Koreans in South Korea. Australia could also take similar initiatives, granting visas selectively to North Korean refugees who find it difficult to adapt to life in South Korea and wish to start a new life elsewhere. There is also obvious scope for Australia to develop schemes, either in South Korea or here in Australia, to provide English-language training for North Korean émigrés.

Huge movements of people - both within and across the boundaries of the rapidly changing nations of Asia-are an inescapable part of the region's future. The twenty-first century is not an age when simple lines can be drawn between the good Consumasians whom we will welcome to our shores to boost our economic growth and the bad 'illegals' who can be kept in their places by tough cross-border policing. The ability to put forward imaginative, long-term and just approaches to tough problems like the North Korean crisis and mass movements of people will be the test of Australia's capacity to contribute to our region's difficult journey into a post-Cold War world.

\section{References}

Agence France-Presse. 2013. UN food body approves $\$ 200$ million food aid to N. Korea. Agence France-Presse 8 June. URL: reliefweb.int/report/democraticpeoples-republic-korea/un-food-body-approves-200-mn-food-aid-n-korea. Consulted 17 March 2015.

Australian Customs and Border Protection Service. 2015. Operation Sovereign Borders: Monthly operational update, January 2015. Canberra: Australian Customs and Border Protection Service. URL: newsroom.customs.gov. au/channels/Operation-Sovereign-Borders/releases/monthly-operationalupdate-january-3. Consulted 7 March 2015.

Bennett, Bruce W. 2013. Preparing for the possibility of a North Korean collapse. Santa Monica and Washington, DC: Rand Corporation.

Berlin Institut für Bevölkerung und Entwicklung. 2007. Not am Mann: Von Helden der Arbeit zu neuen Unterschicht? Berlin: Berlin Institut für Bevölkerung und Entwicklung.

Campbell, Emma. 2011. Changing South Korea: Issues of identity and reunification in formulating the Australia-Korea security policy, foreign policy and wider relationship. Korea Observer 42(1): 117-43.

Commonwealth of Australia. 2012. Australia in the Asian Century. White Paper. Canberra: Commonwealth of Australia. URL: asiancentury.dpmc.gov.au/ white-paper. Consulted 7 October 2013. 
de Groot, Henri, Nijkamp, Peter and Stough, Roger. 2004. Entrepreneurship and regional economic development: A spatial perspective. Cheltenham: Edward Elgar.

Demick, Barbara. 2012. China hires tens of thousands of North Korea guest workers. Los Angeles Times 1 July. URL: articles.latimes.com/2012/jul/01/ world/la-fg-china-workers-20120701. Consulted 17 March 2015.

Hall, Bianca. 2012. Hunger strikers slam 'hell hole' camps on Nauru. Sydney Morning Herald, 6 November.

ICG [International Crisis Group]. 2011. Strangers at home: North Koreans in the south. Asia Report No. 208. Washington, DC: International Crisis Group.

Kim, Mikyoung. 2012. Securitization of human rights: North Korean refugees in East Asia. Santa Barbara: ABC/Clio.

Kwon, Heonik. 2010. The other Cold War. New York: Columbia University Press.

Mirani, Leo. 2013. Mobile phones are booming in North Korea, of all places. Business Insider 26 April. URL: www.businessinsider.com/mobile-phonesare-booming-in-north-korea-of-all-places-2013-4\#ixzz3UcwVaE7R. Consulted 17 March 2015.

O, Tara. 2011. The integration of North Korean defectors in South Korea: Problems and prospects. International Journal of Korean Studies 15(2): 151-69.

Perry, Sharon, Linton, Heidi and Schoolnik, Gary. 2011. Tuberculosis in North Korea. Science 331(21 January): 263.

Republic of Korea Ministry of Unification. n.d. Humanitarian settlement. Seoul: Ministry of Unification. URL: www.unikorea.go.kr/eng/default. jsp?pgname=AFFhumanitarian_settlement. Consulted 27 July 2009.

Samaddar, Ranabir. 1996. Whose Asia is it anyway? Region and nation in South Asia. Calcutta: Pearl Publishers.

Taylor, Mi Ae and Manyin, Mark E. 2011. Non-governmental organizations' activities in North Korea. Washington, DC: Congressional Research Service.

$\mathrm{Xu}$, Jianchu, van Noordwijk, Meine, He, Jun, Kim, Kwang-Ju, Jo, Ryong-Song, Pak, Kon-Gyu, Kye, Un-Hui, Kim, Jong-Sik, Kim, Kwon-Mu, Sim, Yong-Nam, Pak, Je-Un, Song, Ki-Ung, Jong, Yong-Song, Kim, Kwang-Chol, Pang, CholJun and Ho, Myong-Hyok. 2012. Participatory agroforestry development for restoring degraded land in DPR Korea. Agroforestry Systems 85 (24 March): 291-30. 
This text is taken from The Social Sciences in the Asian Century, edited by Carol Johnson, Vera Mackie and Tessa Morris-Suzuki, published 2015 by ANU Press, The Australian National University, Canberra, Australia. 